\title{
SYNTHESIS AND ANTIMICROBIAL ACTIVITY OF SPIRO- OXINDOLE-CHROMENE DERIVATIVE COMPOUNDS BASED CURCUMINOID AND CHALCONE
}

\author{
S. H. Oktavia ${ }^{1}$, A. H. Cahyana ${ }^{1,}$, M. Hapsari ${ }^{1}$, Rika Tri Yunarti ${ }^{1}$ \\ and Agus Rimus Liandi ${ }^{2}$ \\ ${ }^{1}$ Department of Chemistry, Faculty of Mathematics and Natural Sciences, Universitas Indonesia, \\ Depok 16424, Indonesia. \\ ${ }^{2}$ Department of Chemistry, Faculty of Science and Technology, Syarif Hidayatullah State \\ Islamic University Jakarta, South Tangerang 15412, Indonesia. \\ ${ }^{\square}$ Corresponding Author: herrykim@ui.ac.id
}

\begin{abstract}
Multicomponent reactions (MCRs) are an efficient strategy to synthesize various heterocyclic compounds in one pot, and a simple step by combining the reactants in the same flask. In this study, a series of spiro-oxindole substituted chromene rings were synthesized via Knoevenagel and Micheal addition reaction using curcuminoid and chalcone as precursors. The reaction was assisted by Nickel ferrite $\left(\mathrm{NiFe}_{2} \mathrm{O}_{4}\right)$ nanocatalyst in ethanol solvent at $70^{\circ} \mathrm{C}$. $\mathrm{NiFe}_{2} \mathrm{O}_{4}$ was synthesized by the co-precipitation method and characterized by FTIR, XRD, and SEM-EDX. The two spirooxindole-chromene derivatives synthesized with the $\mathrm{NiFe}_{2} \mathrm{O}_{4}$ nanocatalyst were characterized their functional group vibrations and molecular mass by FTIR and GCMS, respectively. Under conditions with the addition of 5\% (w/w) catalyst, the yields of compound 1 and compound 2 were $95 \%$ and $90 \%$. Only compound 2 responded to antibacterial activity test against gram-positive bacteria (Staphylococcus aureus and Bacillus subtilis).

Keywords: Spiro-oxindole, Chromene, Knoevenagel Reaction, $\mathrm{NiFe}_{2} \mathrm{O}_{4}$, Antibacterial Activity.

RASĀYAN J. Chem., Vol. 14, No.3, 2021
\end{abstract}

\section{INTRODUCTION}

Multicomponent reaction (MCR) is a reaction that is carried out using more than two reactants to make a product in the same flask. MCRs allow reactions to build new bonds in one step. ${ }^{1}$ One of the reactions that use MCR is in the synthesis of spiro-oxindole that can be widely distributed for drugs and natural material products. Spirooxindole derivative compounds have a variety of antibacterial ${ }^{2}$, anti-cancer ${ }^{3}$, and significant activity in the heart and Alzheimer's disease. ${ }^{4}$ Based on the research of Ballini et al., the presence of different heterocyclic parts (two or more) in one molecule will increase biocidal activity ${ }^{5}$, such as heterocyclic spiro-oxindole rings, with $4 \mathrm{H}$-chromene substitution. The division of $\mathrm{C}-3$ in spiro-oxindol with pyran/chromene rings (spiropyrans or spiro-oxindole-chromene) ${ }^{6}$ has received attention because of spasmolytic, anticoagulant, diuretic, anticancer, and antinafilactic activities. ${ }^{7}$

The biological potential of spiro-oxindole-chromene always encourages chemists to develop efficiency to synthesize it. ${ }^{6}$ The classic spiro-oxindole-chromene synthesis involves one-pot three-components of condensation between isatin, malononitrile, and $\mathrm{C}-\mathrm{H}$ acid which can be evolved such as dimedone, barbituric acid, naphthols, 4-hydroxycoumarin, resorcinol, 8-hydroxyquinoline ${ }^{7,8}$, but there are no reports of synthesis spiro-oxindole-chromene using curcuminoid and chalcone as precursors.

Currently, to make the reaction more efficient and maximize the product in a short time many researchers have synthesized spiro-oxindole-chromene compounds through the MCR approach using different catalysts such as urea, potassium phthalimide, inorganic salts, $\mathrm{CaCl}_{2}, \mathrm{NH}_{4} \mathrm{Cl}$, tungstate acid, cellulose - $\mathrm{HClO}_{4}$, organic bases (DBU, TEA, DMAP, DABCO), cysteine, L-proline and melamine as donor-acceptor pairs, p-TSA, [TBD] [TFA]. ${ }^{9-20}$ In this study, $\mathrm{NiFe}_{2} \mathrm{O}_{4}$ nanoparticles which have magnetic properties would be used as catalysts in synthesizing spiro-oxindol-chromene derivatives. 
RASĀYAN J. Chem.

Vol. 14 | No. 3 |1990-1997| July - September | 2021

Nickel ferrite $\left(\mathrm{NiFe}_{2} \mathrm{O}_{4}\right)$ nanoparticles have been used for catalytic purposes. In recent years there have been many studies that synthesize organic compounds using $\mathrm{NiFe}_{2} \mathrm{O}_{4}$ catalysts, such as synthesis of 1,4dihydropyran [2,3-c] pyrazole derivatives ${ }^{21}$, cyanation reactions of various types of aryl halides and heteroaryl halides ${ }^{22}$, synthesis spiro [indole-3,2'-pyrrole]-2.5' $\left(1 \mathrm{H}, 1^{\prime} \mathrm{H}\right)$-diones via multi-component condensation reaction ${ }^{23}$, oxidation of thiol disulfides and sulfides to sulfoxide at room temperature using $\mathrm{NiFe}_{2} \mathrm{O}_{4}-\mathrm{H}_{2} \mathrm{O}_{2}{ }^{24}$, formation of substituted $4 \mathrm{H}$-chromene reactions ${ }^{25}$, and synthesis of 1,4-dihydropiridine derivative compound. ${ }^{26}$ Therefore, this study reports the use of $\mathrm{NiFe}_{2} \mathrm{O}_{4}$ nanocatalysts for the synthesis of spiro-oxindole-chromene compounds through multicomponent reactions between isatin, malononitrile, curcuminoid, and hydroxy chalcone compounds. The synthesized compounds were characterized and tested for their bioactivity as antibacterial.

\section{EXPERIMENTAL}

\section{Materials}

All chemicals used were analytical grade not subjected to further purification. These included, $\mathrm{Fe}\left(\mathrm{NO}_{3}\right)_{2} \cdot 6 \mathrm{H}_{2} \mathrm{O}, \mathrm{Ni}\left(\mathrm{NO}_{3}\right)_{2} \cdot 6 \mathrm{H}_{2} \mathrm{O}, \mathrm{NaOH}$, acetophenone, 2-hydroxybenzaldehyde, isatin, malononitrile, curcuminoid, 2-hidroxychalcone, gram-positive bacteria Bacillus Subtilis and Staphylococcus aureus, gram-negative bacteria Pseudomonas aeruginosa and Escherichia coli, DMSO, ethanol, ethyl acetate.

\section{Synthesis of $\mathrm{NiFe}_{2} \mathrm{O}_{4}$ Nanoparticles}

The $\mathrm{NiFe}_{2} \mathrm{O}_{4}$ were synthesized via the co-precipitation method reported by Reza was modified. As much as $3 \mathrm{mmol}$ of $\mathrm{Ni}\left(\mathrm{NO}_{3}\right)_{2} \cdot 6 \mathrm{H}_{2} \mathrm{O}$ and $6 \mathrm{mmol}$ of $\mathrm{Fe}\left(\mathrm{NO}_{3}\right)_{2} \cdot 6 \mathrm{H}_{2} \mathrm{O}$ were added into $25 \mathrm{~mL}$ of deionized water and stirring at room temperature for $30 \mathrm{~min}$. Thereafter, $0.5 \mathrm{M} \mathrm{NaOH}$ solution was added dropwise until the $\mathrm{pH}$ reaches 10 and a brown precipitate is formed then the precipitate was filtered. The precipitate was washed using deionized water to normal $\mathrm{pH}(\mathrm{pH}=7)$ and dried at $60^{\circ} \mathrm{C}$ for $12 \mathrm{~h}$. Then the metal hydroxide composites formed were calcined at $660^{\circ} \mathrm{C}$ for $2 \mathrm{~h}$.

\section{Synthesis of 2-Hydroxychalcone}

The 2-hydroxychalcone synthesis procedure refers to the previous method by replacing vanillin with 2hydroxybenzaldehyde. $15 \mathrm{mmol}$ acetophenone and 2.5 grams $\mathrm{NaOH}$ (in $20 \mathrm{~mL}$ distilled water) were added to 3.36 grams 2-hydroxybenzaldehyde $(15 \mathrm{mmol})$ in $9 \mathrm{~mL}$ ethanol. The mixture was refluxed for 3 hours at $70^{\circ} \mathrm{C}$ and monitored by $\mathrm{TLC} . \mathrm{HCl} 10 \%$ was added until $\mathrm{pH}=1$ to neutralize the mixture. Then the reaction results were separated by extraction method using ethyl acetate and the product was characterized by its functional group vibration and maximum wavelength. The general reaction of 2-hydroxychalcone formation is shown in Scheme-1.

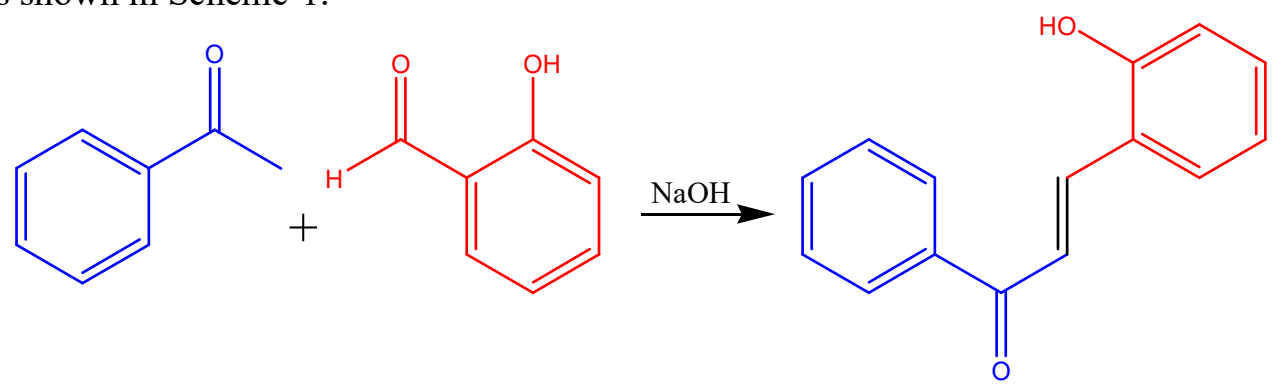

Scheme-1: Claisen-Schmidt Reaction of 2-hydroxychalcone

\section{Synthesis of Spiro-oxindole-chromene Derivative Compounds}

Compound 1 was synthesized by reacting $0.4 \mathrm{mmol}$ isatin, $0.4 \mathrm{mmol}$ malononitrile, and $0.2 \mathrm{mmol}$ curcuminoid. Compound 2 was synthesized by reacting $0.1 \mathrm{mmol}$ isatin, $0.1 \mathrm{mmol}$ malononitrile, and 0.1 mmol 2-hydroxychalcone. Each reaction was assisted by $\mathrm{NiFe}_{2} \mathrm{O}_{4}$ nanocatalyst under reflux condition in ethanol solvent at $70^{\circ} \mathrm{C}$. The reaction was carried out for 4 hours and monitored with TLC. After completion, the mixture was separated from the catalyst using an external magnet and the product was purified by recrystallization with hot ethanol. 
RASĀYAN J. Chem.

Vol. 14 | No. 3 |1990-1997| July - September | 2021

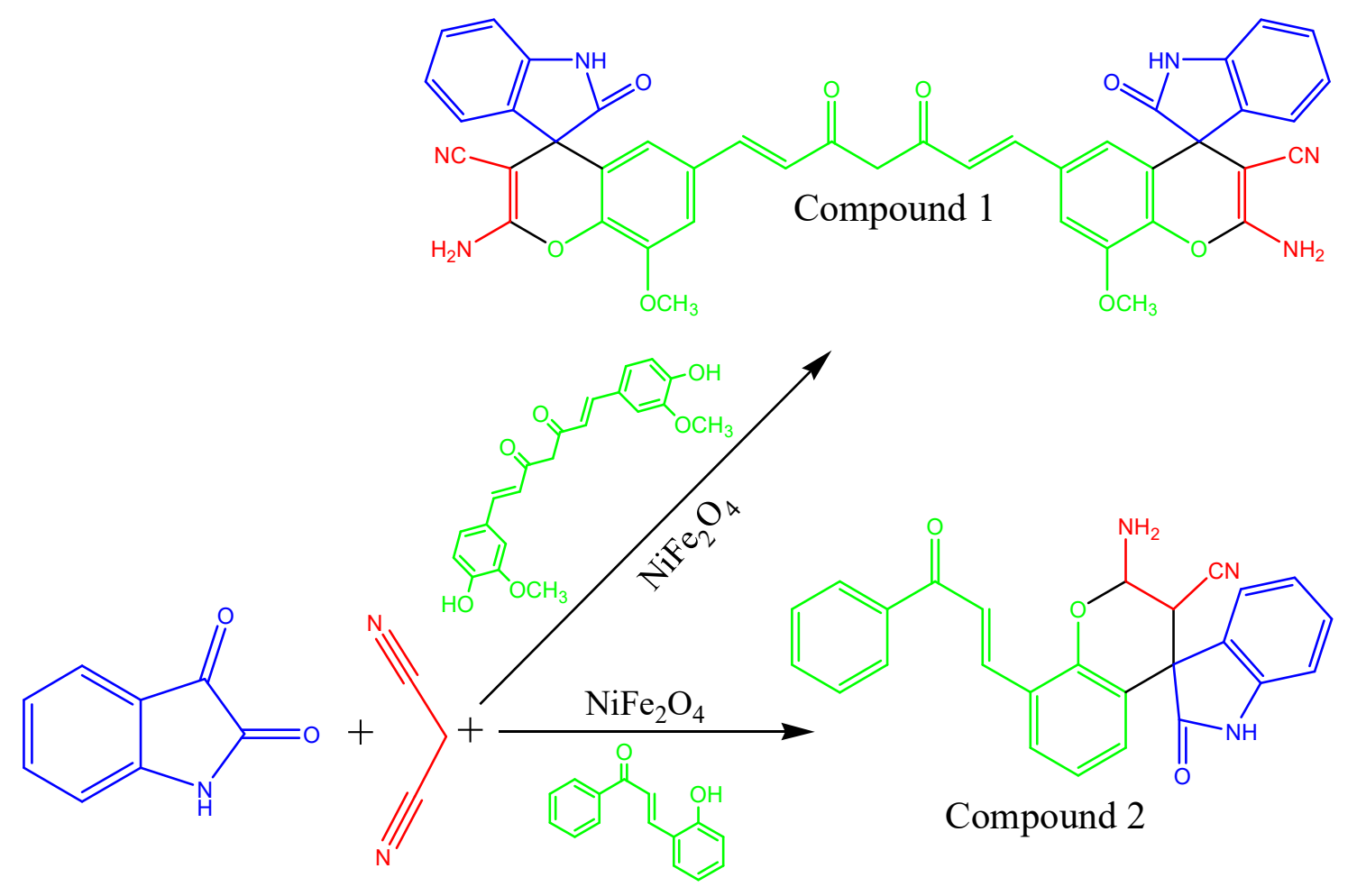

\section{Characterization}

Scheme-2: General Reaction of Compounds 1 and 2

Functional group vibration is measured by Fourier Transform Infrared Spectroscopy (FTIR, Shimadzu series infrared spectrophotometer in $\mathrm{KBr}$ disc). The phase formation was analyzed by X-ray Diffraction (XRD, Malvern Analytical operating at $40 \mathrm{~mA}, 40 \mathrm{kV}$ ). The surface morphologies were scanned by Scanning Electron Microscope (SEM, Sigma Zeiss microscope) and Energy Dispersive X-ray (EDX, Amatek). Mass spectrum was determined by Liquid Chromatography-Mass Spectrometer (LC-MS/MS, UPLC ${ }^{\mathrm{TM}} \mathrm{H}-\mathrm{Class}$ and combined with a Bruker Daltonics Esquire $2000^{\mathrm{TM}}$ ion trap).

\section{Spectral Data of The Representative Compounds}

(E)-3-(2-hydroxyphenyl)-1-phenylprop-2-en-1-one. LC-MS/MS [M+H $\left.\mathrm{H}^{+}\right]$: 225.08 (Rt 10.62). FTIR: $3305.16 \mathrm{~cm}^{-1}(\mathrm{O}-\mathrm{H}) ; 3065.02 \mathrm{~cm}^{-1}\left(\mathrm{C}-\mathrm{H} \mathrm{sp}^{2}\right) ; 1684.89 \mathrm{~cm}^{-1}(\mathrm{C}=\mathrm{O}) ; 1504.54 \mathrm{~cm}^{-1}(\mathrm{C}=\mathrm{C}$ aromatic $)$.

Compound 1: LC-MS/MS [M+H'] 759.2220 (Rt 9.325). FTIR: $3732.41 \mathrm{~cm}^{-1}\left(\mathrm{~N}-\mathrm{H}\right.$ amide); $3521.50 \mathrm{~cm}^{-1}$ (N-H primary); $3585.85 \mathrm{~cm}^{-1}\left(\mathrm{~N}-\mathrm{H}\right.$ primary); $\left.\left.3194.25 \mathrm{~cm}^{-1}(\mathrm{C}-\mathrm{H} \mathrm{sp})^{2}\right) ; 2201.83 \mathrm{~cm}^{-1} \mathrm{C} \equiv \mathrm{N}\right) ; 1732.15 \mathrm{~cm}^{-1}$ $\left(\mathrm{C}=\mathrm{C}\right.$ aromatic); $1619.31 \mathrm{~cm}^{-1}\left(\mathrm{C}=\mathrm{O}\right.$ amide aromatic); $1271.14 \mathrm{~cm}^{-1}$ (C-N stretching); $1034.85 \mathrm{~cm}^{-1}(\mathrm{C}-\mathrm{N})$; $754.19 \mathrm{~cm}^{-1}$ (N-H wag); $685.72 \mathrm{~cm}^{-1}$ (C-H aromatic).

Compound 2: LC-MS/MS [M+H] $]^{+}: 420.13$ (Rt 7.808). FTIR: $3640.79 \mathrm{~cm}^{-1}\left(\mathrm{~N}-\mathrm{H}\right.$ amide); $3368.82 \mathrm{~cm}^{-1}$ $\left(\mathrm{N}-\mathrm{H}\right.$ primary); $3351.46 \mathrm{~cm}^{-1}(\mathrm{~N}-\mathrm{H}$ primary $\left.) ; 3091.06 \mathrm{~cm}^{-1}(\mathrm{C}-\mathrm{H} \mathrm{sp})^{2}\right) ; 2213.41 \mathrm{~cm}^{-1}(\mathrm{C} \equiv \mathrm{N}) ; 1723.47 \mathrm{~cm}^{-1}$ $\left(\mathrm{C}=\mathrm{C}\right.$ aromatic); $1654.03 \mathrm{~cm}^{-1}\left(\mathrm{C}=\mathrm{O}\right.$ amide aromatic); $1227.74 \mathrm{~cm}^{-1}\left(\mathrm{C}-\mathrm{N}\right.$ stretching); $1019.42 \mathrm{~cm}^{-1}(\mathrm{C}-\mathrm{N})$; $758.05 \mathrm{~cm}^{-1}$ (N-H wag); 689.58 (C-H aromatic)

\section{Antibacterial Activities}

All of the synthesized products were examined for their antibacterial activities against gram-negative bacteria (Pseudomonas aeruginosa and Escherichia coli) and gram-positive bacteria (Bacillus Subtilis and Staphylococcus aureus) using the disc diffusion method. ${ }^{27}$ The compound to be tested was made in a concentration of $1000 \mathrm{ppm}$, which is $0.005 \mathrm{~g}$ of the synthesized compound dissolved in $5 \mathrm{~mL}$ DMSO. The 0.5 MacFarland standard bacterial cells were spread on the surface agar plate. Impregnate each disc into 50 
$\mu \mathrm{L}$ of the synthesized compounds and placed it on the agar media. Then, all plate was incubated at $37^{\circ} \mathrm{C}$ for $24 \mathrm{~h}$. After an incubation period of observation and measurement of the clear zone that occurs.

\section{RESULTS AND DISCUSSION}

The bonds formed in the $\mathrm{NiFe}_{2} \mathrm{O}_{4}$ nanoparticles are confirmed with Fourier Transform Infrared Spectroscopy (FTIR). Each bond of a functional group will have a different vibration when measured by FTIR. The $\mathrm{NiFe}_{2} \mathrm{O}_{4}$ FTIR spectrum can be seen in Fig.-1.

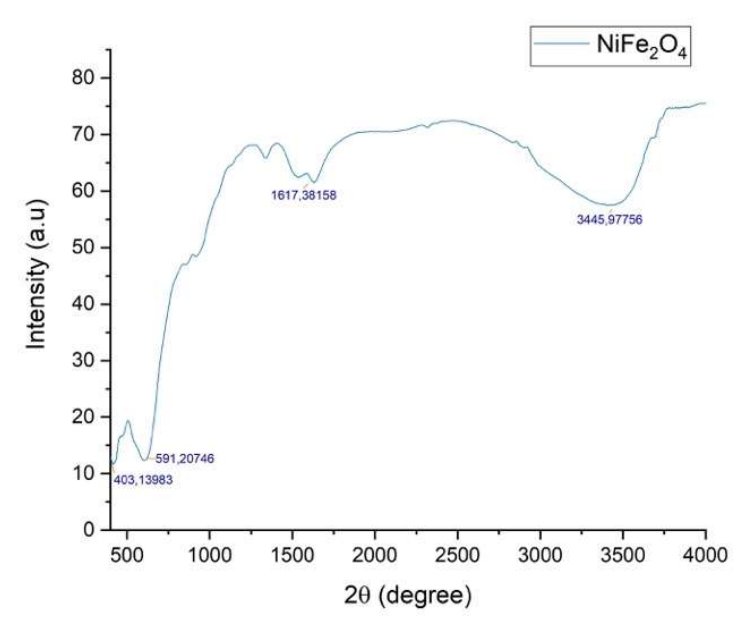

Fig.-1: FTIR Spectrum of $\mathrm{NiFe}_{2} \mathrm{O}_{4}$ Nanoparticles

Figure-1. shows the FTIR absorption spectrum of $\mathrm{NiFe}_{2} \mathrm{O}_{4}$ functional group vibration $\left(400-4000 \mathrm{~cm}^{-1}\right)$. Based on the test results, the absorption peaks appear at wavenumbers $3445.97 ; 1617.38 ; 591.20$ and 403.13 $\mathrm{cm}^{-1}$. Wavenumber $3445.97 \mathrm{~cm}^{-1}$ is vibration stretching between $\mathrm{O}$ and $\mathrm{H}$ atoms. The broad peak indicates the $\mathrm{O}-\mathrm{H}$ groups participating in $\mathrm{H}$-bonding interactions to a certain degree. The peak at $1617.38 \mathrm{~cm}^{-1}$ is O$\mathrm{H}$ bending group. The two main peaks of metal and oxygen ion absorption groups related to the ferrite spinel structure in $\mathrm{NiFe}_{2} \mathrm{O}_{4}$ synthesis are in the range of $400-600 \mathrm{~cm}^{-1}$. The first peak is at $591.20 \mathrm{~cm}^{-1}$ and the second at $403.13 \mathrm{~cm}^{-1}$, each related to the octahedral and tetrahedral sites of the position of the metal ions in the ferrite spinel. ${ }^{28}$ The ferrite spinel structure of $\mathrm{NiFe}_{2} \mathrm{O}_{4}$, all $\mathrm{Ni}^{2+}$ will be on the octahedral side while the $\mathrm{Fe}^{3+}$ ions will be distributed evenly on the octahedral and tetrahedral parts. Therefore, the absorption peak that appears at the wave number $403.13 \mathrm{~cm}^{-1}$ is the absorption group of atoms at the octahedral site (vibrations from $\mathrm{Ni}, \mathrm{Fe}$ and $\mathrm{O}$ ), while the absorption peak that appears at the wave number $591.20 \mathrm{~cm}^{-1}$ is the absorption group of atoms at the tetrahedral site (vibrations from $\mathrm{Fe}$ and O) ${ }^{29}$ Open octahedral sites can provide empty orbitals that allow for reactions. ${ }^{30}$

Fig.-2. illustrate the X-ray diffraction of $\mathrm{NiFe}_{2} \mathrm{O}_{4}$ nanoparticles. From the results of XRD analysis on nanoparticles, it can be seen that there is a typical peak of $\mathrm{NiFe}_{2} \mathrm{O}_{4}$ at $2 \theta 30.34^{\circ} ; 35.76^{\circ} ; 37.24^{\circ} ; 43.31^{\circ}$; $54.20^{\circ} ; 57.42^{\circ} ; 63.06^{\circ}$. These peaks indicate the formation of $\mathrm{NiFe}_{2} \mathrm{O}_{4}$ (JCPS: $01-074-2081$ ) and the crystal structure was cubic spinel. ${ }^{31}$ However, there was another peak at $2 \theta 33.21^{\circ}$ which is a typical peak of the $\alpha-\mathrm{Fe}_{2} \mathrm{O}_{3}$ (hematite) phase is antiferromagnetic. While $\mathrm{NiFe}_{2} \mathrm{O}_{4}$ is ferrimagnetic, therefore the presence of hematite in the $\mathrm{NiFe}_{2} \mathrm{O}_{4}$ can contribute to the magnetic properties of $\mathrm{NiFe}_{2} \mathrm{O}_{4}$ nanoparticles. Based on XRD data, the crystal size of the $\mathrm{NiFe}_{2} \mathrm{O}_{4}$ nanoparticles was calculated using the Debye-Scherrer equation.

$$
D=\frac{0,9 \lambda}{\beta \cos \theta}
$$

Where, $\lambda$ is the electromagnetic wavelength (nm), while $\beta$ is the peak width of the half-peak (FWHM) in radians, and $\theta$ is the Bragg angle position. From calculations using these equations, the crystal size of $\mathrm{NiFe}_{2} \mathrm{O}_{4}$ is $23.15 \mathrm{~nm}$. 
RASĀYAN J. Chem.

Vol. 14 | No. 3 |1990-1997| July - September | 2021

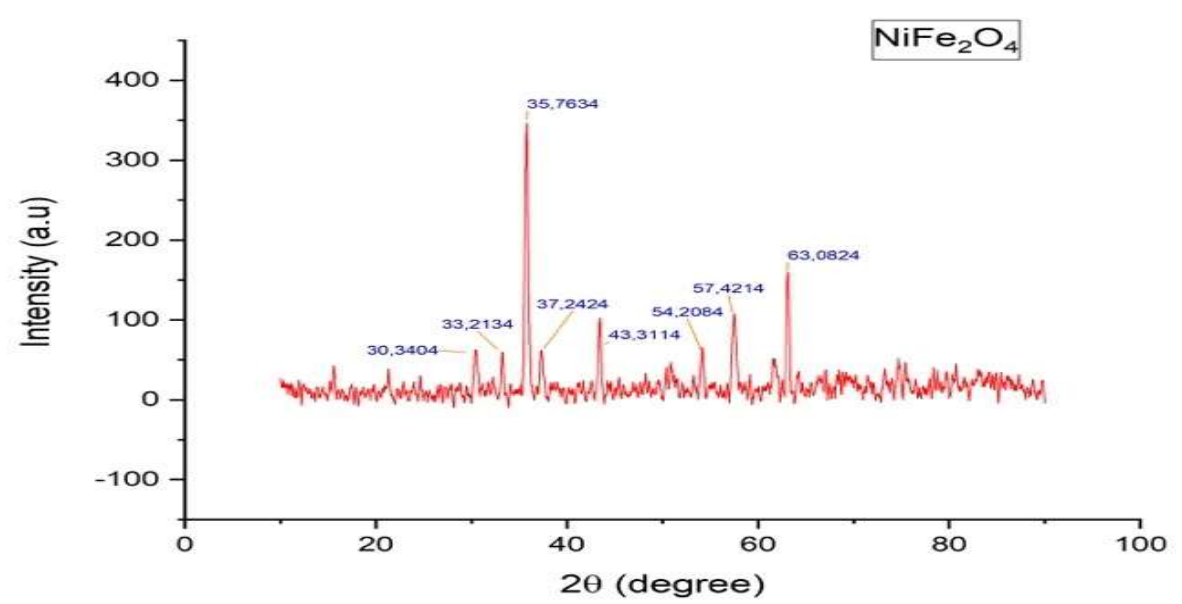

Fig.-2: XRD Patterns of $\mathrm{NiFe}_{2} \mathrm{O}_{4}$

Morphology and surface of $\mathrm{NiFe}_{2} \mathrm{O}_{4}$ nanoparticles were investigated by scanning electron microscopy (SEM). SEM analysis shows that $\mathrm{NiFe}_{2} \mathrm{O}_{4}$ nanoparticles do not have a uniform size. ${ }^{32}$ The white granules seen on the surface are due to the induction of $\mathrm{Fe}$ in $\mathrm{Ni}$. The average particle size of $\mathrm{NiFe}_{2} \mathrm{O}_{4}$ nanoparticles based on SEM results is $71.65 \mathrm{~nm}$. SEM micrographs illustrate that the sample contains a micrometric aggregation of small particles. The agglomeration shows that crystallites have pores on the surface. The SEM image shows the agglomerated form of $\mathrm{NiFe}_{2} \mathrm{O}_{4}$ nanoparticles. Because nanoparticles have high surface energy, they usually agglomerate and grow into larger aggregate. ${ }^{33}$

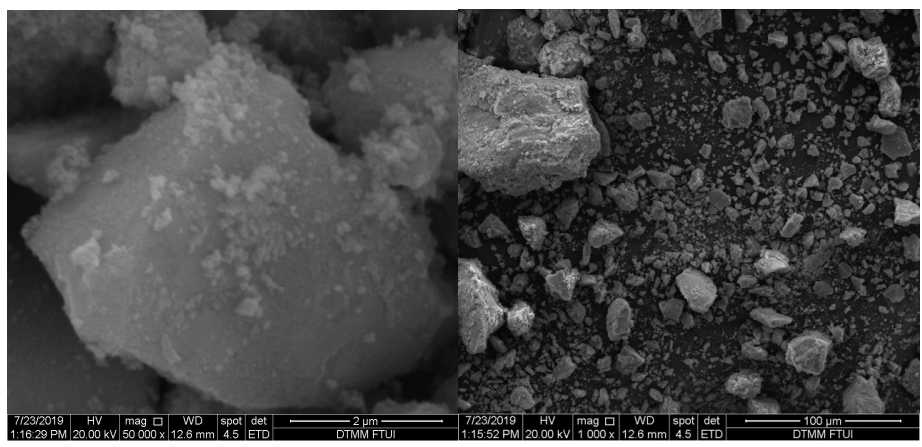

Fig.-3: Morphology of $\mathrm{NiFe}_{2} \mathrm{O}_{4}$ Nanoparticles with SEM

The scanning electron microscope (SEM) can also be used to find out information on the composition of elements contained in a sample by detecting characteristic X-rays. The EDX analysis is used to evaluate the elemental composition of $\mathrm{NiFe}_{2} \mathrm{O}_{4}$ nanoparticles. Based on Fig.-4. the existence of $\mathrm{Ni}, \mathrm{Fe}$, and $\mathrm{O}$ elements is already approaching the $\mathrm{NiFe}_{2} \mathrm{O}_{4}$ atomic ratio of 1:2: 4 .
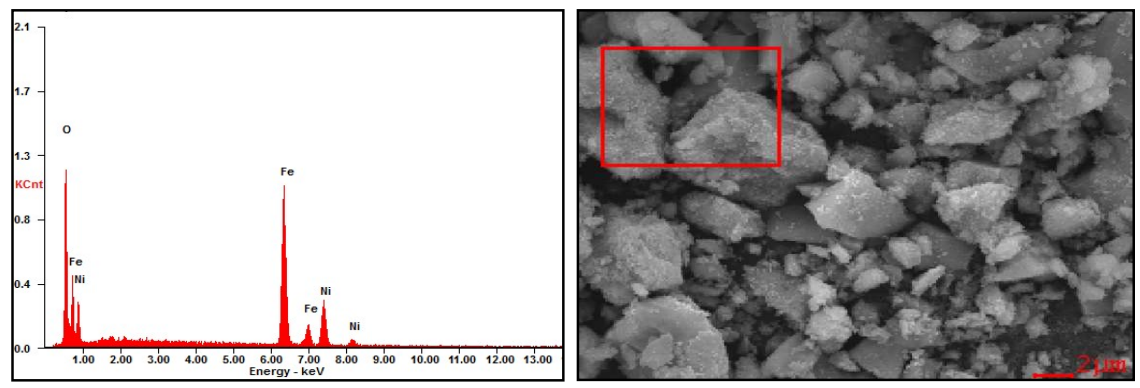

Fig.-4: The EDX Patterns of $\mathrm{NiFe}_{2} \mathrm{O}_{4}$ Nanoparticles 
The various amount of catalyst in the reaction was applied to optimize the reaction condition for the synthesis of spiro-oxindole-chromene on the reaction of isatin, malononitrile and curcuminoid/ 2hydroxychalcone is examined (Table-1). The two of spiro-oxindole-chromene derivatives synthesized namely 2-amino-6-((1E,6E)-7-(2-amino-3-cyano-8-methoxy-2'-oxospiro[chromene-4,3'-indolin]-5-yl)3,5-dioxohepta-1,6-dien-1-yl)-8-methoxy-2'-oxospiro[chromene-4,3'-indoline]-3-carbonitrile (compound 1), and (Z)-2-amino-2'-oxo-8-(3-oxo-3-phenylprop-1-en-1-yl)spiro[chromene-4,3'-indoline]-3-carbonitrile (compound 2). From Table-1, it was showed that the addition of $5 \% \mathrm{NiFe}_{2} \mathrm{O}_{4}$ nanoparticles was sufficient to complete the reaction in 4 hours and produced good yields in $10 \mathrm{~mL}$ ethanol as a solvent. Increasing the amount of catalysts by more than $5 \%$ could not increase the yield in the reaction, it proves that $\mathrm{NiFe}_{2} \mathrm{O}_{4}$ is an efficient catalyst and can be used in organic reactions.

Table-1: Optimization of the Catalyst Concentration in the Reaction

\begin{tabular}{c|c|c|c}
\hline Entry & $\mathrm{NiFe}_{2} \mathrm{O}_{4}$ & Compound 1 & Compound 2 \\
\hline 1 & $0 \%$ & trace & trace \\
\hline 2 & $5 \%$ & $95 \%$ & $90 \%$ \\
\hline 3 & $10 \%$ & $90 \%$ & $86 \%$ \\
\hline
\end{tabular}

Evaluation of the biological activity of spiro-oxindole-chromene derivatives was tested as antibacterial agents against various types of gram-negative and gram-positive bacteria using the disk diffusion method. From the test, the antibacterial activity of the spiro-oxindole-chromene compounds is shown in Table 2. Only compound 2 responded to antibacterial activity test against gram-positive bacteria (Bacillus subtilis and Staphylococcus aureus).

Table-2: Antibacterial Activity of Spiro-oxindole-chromene

\begin{tabular}{c|c|c|c|c|c}
\hline \multirow{2}{*}{ Code } & \multirow{2}{*}{ Parameter } & \multicolumn{4}{|c}{ Inhibition Zone in mm } \\
\cline { 3 - 6 } & & B. subtilis & E. coli & S. aureus & P. aeruginosa \\
\hline AB & Antibiotic Gentamicin & 11.57 & 13.6 & 10.28 & 11.74 \\
\hline 968 & Compound 1 & - & - & - & - \\
\hline 969 & Compound 2 & 7.5 & - & 9.4 & - \\
\hline DMSO & DMSO & - & - & - & - \\
\hline
\end{tabular}

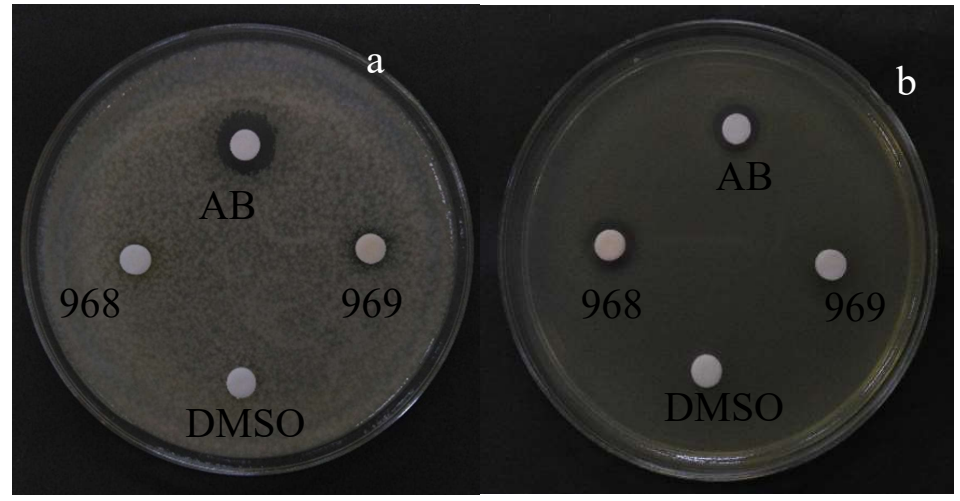

Fig.-5: Antibacterial Activity (a) B.subtilis (b) S.aureus

\section{CONCLUSION}

An efficient and simple procedure for synthesis of spiro-oxindole-chromene has been found by multicomponent reaction of isatin, malononitrile, and curcuminoid/2-hydroxychalcone in $10 \mathrm{~mL}$ ethanol at $70^{\circ} \mathrm{C}$ in the presence of $\mathrm{NiFe}_{2} \mathrm{O}_{4}$ as an efficient catalyst. The two of spiro-oxindole-chromene derivatives synthesized namely 2-amino-6-((1E,6E)-7-(2-amino-3-cyano-8-methoxy-2'-oxospiro[chromene-4,3'indolin]-5-yl)-3,5-dioxohepta-1,6-dien-1-yl)-8-methoxy-2'-oxospiro[chromene-4,3'-indoline]-3carbonitrile (compound 1), and (Z)-2-amino-2'-oxo-8-(3-oxo-3-phenylprop-1-en-1-yl)spiro[chromene-4,3'indoline]-3-carbonitrile (compound 2) Therefore, based on the screened spiro-oxindole-chromene 
RASĀYAN J. Chem.

Vol. 14 | No. 3 |1990-1997| July - September | 2021

derivates, compound 2 was considerably promising as an antibacterial agent with inhibition zone $7.5 \mathrm{~mm}$ for $B$. subtilis and $9.4 \mathrm{~mm}$ for $P$. aureginosa, respectively.

\section{ACKNOWLEDGMENT}

This work was financially supported by University of Indonesia through PITTA A Grant of No. NBK0432/UN2.R3.1/HKP.05.00/2019.

\section{REFERENCES}

1. N. Nurhikmah, A. H. Cahyana, and A. R. Liandi, AIP Conference Proceedings, 2242, 040023 (2020), https://doi.org/10.1063/5.0007886

2. G. Bhaskar, Y. Arun, C. Balachandran, C. Saikumar and P. T. Perumal, European Journal of Medicinal Chemistry, 51, 79(2012), https://doi.org/10.1016/j.ejmech.2012.02.024

3. R. K. Singh, D. N. Prasad and T. R. Bhardwaj, Medicinal Chemistry Research, 24(4), 1534(2015), https://doi.org/10.1007/s00044-014-1236-1

4. K. Sugimoto, K. Tamura, C. Tohda, N. Toyooka, H. Nemoto and Y. Matsuya, Bioorganic and Medicinal Chemistry, 21(15), 4459(2013), https://doi.org/10.1016/j.bmc.2013.05.059

5. R. Ballini, G. Bosica, L. Conforti, R. Maggi, A. Mazzacani and G. Sartori, Tetrahedron, 57, 1395(2001), https://doi.org/10.1016/S0040-4020(00)01121-2

6. S. S. Khot, P. V. Anbhule, U. V. Desai and P. P. Wadgaonkar, Comptes Rendus Chimie, 21(9), 814(2018), https://doi.org/10.1016/j.crci.2018.05.005

7. J. Skommer, D. Wlodkowic and M. Mikko, Leukemia Research, 30, 322(2006), https://doi.org/10.1016/j.leukres.2010.10.020

8. R. G. Shi and C. G. Yan, Chinese Chemical Letters, 27(4), 575(2016), https://doi.org/10.1016/j.cclet.2016.02.016

9. G. Brahmachari and B.Banerjee, American Chemical Society, 2, 411(2014), https://doi.org/10.1021/sc400312n

10. A. Gupta, R. Jamatia and A. K. Pal, New Journal of Chemistry, 39(7), 5636(2015), https://doi.org/10.1039/C5NJ00657K

11. J. Feng, K. Ablajan and A. Sali, Tetrahedron, 70(2), 484(2014), https://doi.org/10.1016//j.tet.2013.11.019

12. M. G. Dekamin and M. Eslami, Green Chemistry, 16(12), 4914(2014), https://doi.org/10.1039/C4GC00411F

13. J. Davarpanah, and A. R. Kiasat, RSC Advances, 4(9), 4403(2014), https://doi.org/10.1039/C3RA43443E

14. M. Dabiri, M. Bahramnejad and M. Baghbanzadeh, Tetrahedron, 65(45), 9443(2009), https://doi.org/10.1016/j.tet.2009.08.070

15. T. Khan and Z. N. Siddiqui, New Journal of Chemistry,38(10), 4847(2014), https://doi.org/10.1039/C4NJ00529E

16. S. L. Zhu, S. J. Ji and Y. Zhang, Tetrahedron, 63(38), 9365(2007), https://doi.org/10.1016/j.tet.2007.06.113

17. A. Khalafi-Nezhad, M. Divar and F. Panahi, RSC Advances, 5(3), 2223(2015), https://doi.org/10.1039/C4RA12976H

18. S. Nagaraju, B. Paplal, K. Sathish, S. Giri and D. Kashinath, Tetrahedron Letters, 58(44), 4200(2017), https://doi.org/10.1016/j.tetlet.2017.09.060

19. J. Khosrow, G. Ramin and B. Ayoob, Journal of Combinatorial Chemistry, 11, 341(2009), https://doi.org/10.1021/cc800167h 
20. S. Meysam, M. Tajbakhsh and M. Farhang, Comptes Rendus Chimie, 17(12), 1160(2014), https://doi.org/10.1016/j.crci.2013.12.005

21. M. Reza, P. Heravi and N. Morsalie, Irian Chemical Communication, 6, 87(2018).

22. M.F. Matloubi, G. Tavakoli and H. R. Rezvani, Applied Organometallic Chemistry, 28(10), 750(2014), https://doi.org/10.1002/aoc.3191

23. Amol P. Amrute, Suman Sahoo, Ankur Bordoloi, Young Kyu Hwang, Jin-Soo Hwang, Shiva B. Halligudi, Catalysis $\quad$ Communications, $\quad$ 10(10), https://doi.org/10.1016/j.catcom.2009.03.007

24. A. M. Kulkarni, U. V. Desai, K. S. Pandit, M. A. Kulkarni and P.P. Wadgaonkar, RSC Advances, 4(69), 36702(2014), https://doi.org/10.1039/C4RA04095C

25. H. Ahankar, A. Ramazani, K. Slepokura, T. Lis and S. W. Joo, Turkish Journal of Chemistry, 42(3), 719(2018), http://dx.doi.org/10.3906/kim-1710-14

26. A. H. Cahyana, A. R. Liandi, Y. Safitri, and R. T. Yunarti, Rasayan Journal of Chemistry, 13(3), 1491(2020), http://dx.doi.org/10.31788/RJC.2020.1335700

27. M. Hapsari, A. H. Cahyana, S. H. Oktavia, and A. R. Liandi, Rasayan Journal of Chemistry, 13(4), 2317(2020), http://dx.doi.org/10.31788/RJC.2020.1345583

28. A. H. Cahyana, A. R. Liandi, Y. Yulizar, Y. Romdoni and T. P. Wendari, Ceramics International, 13(4), 2317(2020), https://doi.org/10.1016/j.ceramint.2021.04.146

29. A. Hajalilou, M. Hashim, R. E. Ebrahimi-Kahrizsangi, H. M. Kamari and N. Sarami, Ceramics International, 47(15), 21373(2021), https://doi.org/10.1016/j.ceramint.2013.11.032

30. Q. Li, X. Wang, Y. Yu, Y. Chen and L. Dai, Tetrahedron, 72(50), 8358(2016), https://doi.org/10.1016/j.tet.2016.11.011

31. H. Ahankar and A. Ramazan, Research on Chemical Intermediates, 42(3), 2487(2015), https://doi.org/10.1007/s11164-015-2163-6

32. V. V. Dabholkar, S. K. Kurade and K. S. Badhe, International Journal of Latest Technology in Engineering, Management \& Applied Science, 5(8), 34(2016).

33. S. Sagadevan, Z. Z. Chowdhury and R. F. Rafique, Materials Research, 21(2), 21(2018), https://doi.org/10.1590/1980-5373-MR-2016-0533

[RJC-5546/2020] 